\title{
The importance of androgen receptors in breast cancer
}

Irina Niță ${ }^{1,2}$, Cornelia Nițipir ${ }^{1,2}$, Ștefania Andreea Toma ${ }^{3}$, Alexandra Maria Limbău ${ }^{4}$, Edvina Pîrvu ${ }^{5}$, Ioana Anca Bădărău ${ }^{1}$

1) Carol Davila University of Medicine and Pharmacy, Bucharest, Romania

2) Medical Oncology Department, Elias University Emergency Hospital, Bucharest, Romania

3) Medical Oncology Department, Ponderas Academic Hospital Bucharest, Romania

4) Dermatology Department, Municipal Hospital Curtea de Argeș, Romania

5) Medical Oncology Department, "Colţea" Clinical Hospital, Bucharest, Romania

DOI: $10.15386 / \mathrm{mpr}-1842$

Manuscript received: 05.08.2020

Received in revised form: 05.11.2020

Accepted: 03.02.2021

Address for correspondence:

irina.nita0910@gmail.com

This work is licensed under a Creative Commons Attribution-NonCommercialNoDerivatives 4.0 International License

\section{Introduction}

Breast cancer (BC) is the most common solid tumor evidenced in women and the principal leading cause of cancer death in the young women population. The treatment of this malignant condition requires a multidisciplinary approach involving surgical oncology, radiation oncology and medical oncology, which has been associated with a reduction in $\mathrm{BC}$ mortality. In oncology, the main goals are to increase the curability rate in the adjuvant setting and the survival in the event of metastases. The main research trends are the molecular subcategorization of $\mathrm{BC}$ and the development of new targeted endocrine therapy [1].

It is known that the presence of estrogen receptor (ER) and progesterone receptors $(\mathrm{PgR})$ is associated with better outcome for women with $\mathrm{BC}$, but also with multiple possibilities of therapeutic strategies. Considering that the $\mathrm{BC}$ cells can acquire resistance to hormonal therapies, the attention has focused on the role of the androgens and androgen receptor (AR) as a prognostic marker and therapeutic targets $[2,3]$.

Pragmatic clinicians divide breast tumors into three types: those requiring hormonal therapy, those requiring antihuman epidermal growth factor receptor 2 (Her 2) therapy and those requiring chemotherapy. Regardless of the group in which patients fall, special attention must be paid to risk factors, in order to ensure good therapeutic compliance [4-8]. 


\section{Diagnosis of $\mathrm{BC}$}

$\mathrm{BC}$ combines diseases with different evolution and prognosis. The molecular sub-classification is most commonly used, breast tumors being divided according to the presence of hormonal receptors, the protein her2 and the proliferation score $\mathrm{Ki}-67$, in $[9,10]$ :

- Luminal A: ER positive, Her 2 negative, Ki67 low, PgR high

- Luminal B: Her- negative: ER positive, Her 2 negative and either Ki67 high or PgR low

- Her-positive: ER positive, Her 2 positive, any Ki67 high or PgR

- Her 2: Her 2 positive, ER and PgR negative

- Basal like or Triple negative: ER, PgR, Her 2absent

$\mathrm{BC}$ has molecular heterogeneity and although there are multiple molecular targeted therapies, BC mortality remains high. This explains why it is necessary to develop therapeutic strategies including new drugs, especially for triple negative breast cancer (TNBC). In this context, $\mathrm{AR}$ is a possible new marker option and a potential new therapeutic target $[11,12]$.

The AR is expressed in more than $50 \%$ of $\mathrm{BC}$, but the presence may vary with the antibody used for immunohistochemistry (IHC) and the cut-off of expression. The prognostic role of AR seems to be favourable for $\mathrm{BC}$, but clinical trials are needed to better define AR's prognostic role in different $\mathrm{BC}$ subtypes. Those receptors can be stimulated by circulating androgens which are detected physiological during life [13-15].

AR is a member of the steroid hormone family of receptors, together with estrogenic, progesterone and glucocorticoid receptors. It is a steroid hormone with nuclear receptor, which in vitro has both inhibitory and stimulatory effects on different BC cell lines growth, probably correlated with the presence or absence of the ER expression. Considering the importance of $\mathrm{AR}$ in $\mathrm{BC}$, there are many authors who propose that its identification become routine and be part of the quadruple panel, together with the estrogenic, PgR and human epidermal growth factor receptor $2[16,17]$.

\section{AR mechanism of action}

In women, the circulating androgens are mainly secreted by the adrenal glands (dehydroepiandrosteronesulfate - DHEAS, dehydro-androstenedione - DHEA, androstenedione - A4) and by the ovaries (testosterone, A4, DHEA). In the peripheral tissues, such as brain, bone and breast, testosterone, DHT and their metabolites are produced. These hormones play a role in reproductive system, muscle growth and bone loss prevention $[18,19]$.

The concentration of androgen hormones differs during life, the secretion of testosterone decreases in the period of reproductive years and is still present in the menopause period because the androgens ovarian production declines less drastically than the estrogen and progesterone [19].

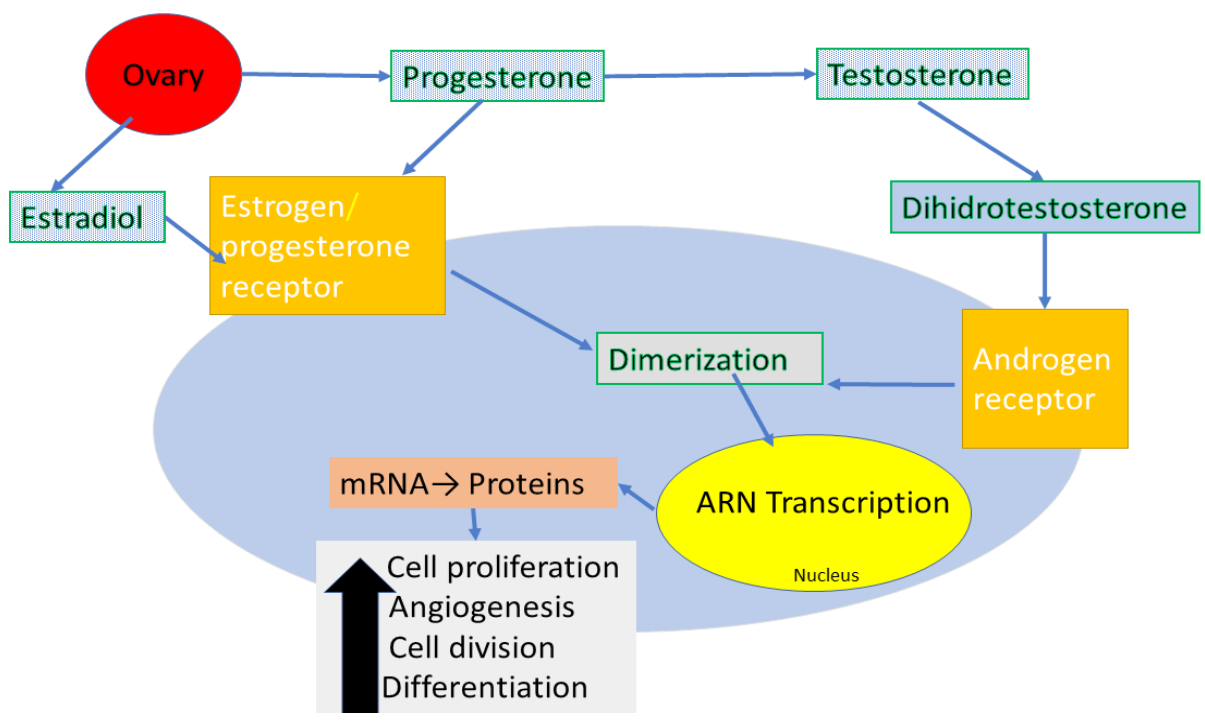

Figure 1. Hormonal receptor activation. Transcriptional/ genomic modality of AR activation: receptor-hormone complex translocates into the nucleus and interacts with co-activators, co-repressor and transcription modulators. As a result, it promotes the transcription of target genes resulting proteins which promotes the cancer cell. 
The role of androgens in $\mathrm{BC}$ seems to have dual effect, both pro- and anti- tumorigenic. Blood androgens are ligands that bind the membrane AR, which is internalized in the cytoplasm and subsequently transported to the nucleus, where it exerts its effects. The activation of targeted gene transcription leads to mRNA synthesis and subsequent protein synthesis, which finally determine cell proliferation, angiogenesis, cell division and differentiation. Without the ligand, the unbound AR is found in cytoplasm in a complex together with heat shock proteins [20-22].

In vitro data suggest that the presence of the $\mathrm{AR}$ on $\mathrm{BC}$ cell may play an important role in promoting tumor development (Figure 1). This mechanism was studied in all type of cancer cells. For example, in ER positive cells, high concentrations of the androgen $5 \alpha$-dehydro-testosterone has shown to cause inhibition of proliferation and cell survival in human $\mathrm{BC}$ cell lines expressing both ER and AR. In the same cell lines, activation of AR with dehydrotestosterone leads to a competition between the estrogen and androgen signaling at the nucleus level which one had decreased estrogen- dependent signaling, a similar effect was seen after Tamoxifen administration. Therefore, it is possible that the expression of AR would be associated with reduced cell proliferation and apoptosis [23-25].

On the other hand, the way in which AR acts in tumors with negative ER, PgR and Her2, the triple negative subset, remains incompletely characterized in the area of active research. The preclinical laboratory work, on xenograft murine models and cell lines, suggests that tumor proliferations in this subtype are dependent on the androgen signaling, together with the AR presence. Furthermore, there were some studies, on the same models, with AR-inhibitors or blockers, such as enzalutamide or bicalutamide, with good results. The investigators showed that the androgen signaling, and stimulation of AR is necessary for cell survival and proliferation [26,27].

AR gene is located on the chromosome Xq11-12 and it consists of four domains, an N-terminal domain, a DNAbinding domain, a hinge and a ligand binding domain which acts as a nuclear transcription factor. The effect depends on the presence of the ligand, if this is present, AR translocate into the nucleus, where the DNA-binding domain binds the androgen- responsive elements in DNA and recruits additional co-activators, co-repressors, and transcriptional modulators. In the absence of a ligand, AR attaches to heat shock proteins which are in the cytoplasm $[28,29]$.

In inactive state, the AR is located in the cytoplasm, bound to heat shock proteins. In case of stimulation, the circulating androgens bind to the $\mathrm{C}$-terminal binding domain leading to a conformational change which allows AR dimerization. It translocases into the nucleus and leads to an effect depending on the presence of ER and PgR. In ER positive tumors, AR can promote spread of cancer cell and the resistance to hormonal therapies [23,30,31].

Although most publications discuss $\mathrm{AR}$ as a prognostic factor in $\mathrm{BC}$ patients, some reports also found an association between AR and therapy response. First, AR was assumed to be a predictive marker for response to endocrine treatment in BC patients. Then, AR was evaluated in ERpositive tumors and a prognostic role of AR could be basically seen in chemo-endocrine treated patients. Additionally, Park et al. described no effect of high AR expression levels on chemotherapy benefit in ER-positive patients, but concluded that patients with low AR expression could be ideal candidates for chemotherapy treatment [3,32-35].

\section{Methods}

We searched Pubmed, ScienceDirect, Scopus and Web of Knowledge for articles written in English and published after December 2000. Search terms were androgen receptors, breast cancer, risk and women, alone and in combination. In addition, abstracts from annual meetings of the American Society of Medical Oncology, European Society of Medical Oncology were screened. There was no restriction based on study methodology.

\section{Criteria for the selections of studies}

The investigators reviewed every article quoted in this paper and appreciated the possibility to include them in this research according the following inclusion criteria: original and review articles, IHC determination of AR in $\mathrm{BC}$ patients, studies that showed the survival outcome after primary treatment, determination of progression free survival or overall survival according to the expression of AR, publication in English. Editorial letters, case reports, animal testing research paper, studies that included men, duplicated articles and non-English articles were excluded. Also, we excluded the articles with no access to the full text of the article.

\section{Results}

Figure 2 shows the flow chart of this article. A total of 343 articles were found by using the keywords described above. Finally, after we read the titles and the contents and eliminated the duplicates or the articles that were not related to our concern, we selected and analyzed the rest.

In table I we have summarized the relevant articles for the approached subject and the practical implications resulting in these studies.

\section{$A R$ and primary $B C$}

In a large study conducted by Elebro et al. ( $\mathrm{n}=910)$, the authors demonstrated that the AR expression is an important prognostic factor and may have a negative impact the outcome of the patients, especially the AR+/ ER- [36].

Park et al. assessed AR expression using IHC from 413 whole sections and analyzed the tumor characteristic in the presence of AR. They observed that the expression was significant with no elevated preoperative serum cancer antigen 15-3 levels, smaller tumor size, lower tumor grade and hormone receptor-positive and non-triple-negative $\mathrm{BC}$. Regarding the histological type, AR was less present in metaplastic, medullary and mucinous types of carcinomas [37]. 


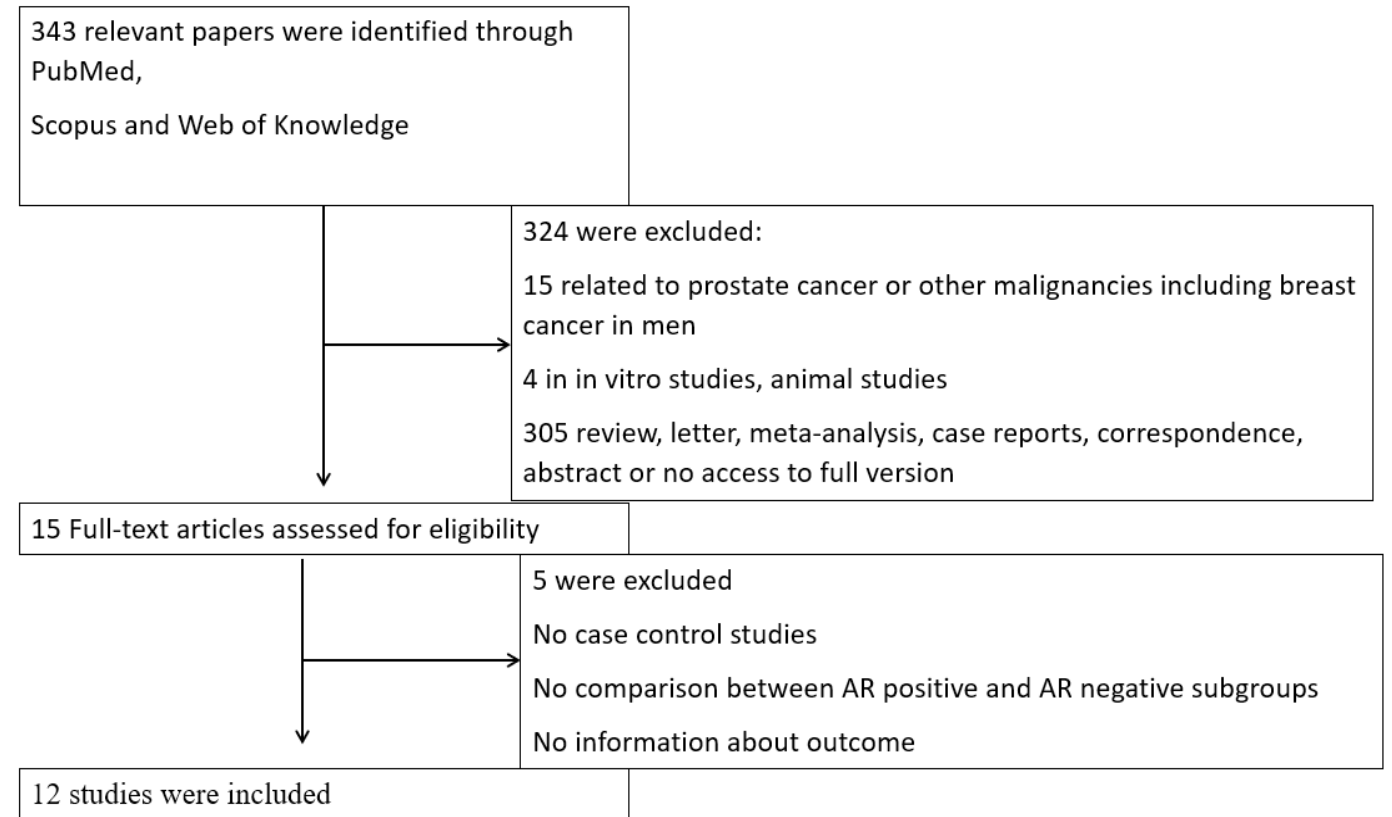

Figure 2. Flow diagram of the study.

Table I. Characteristics of the included studies.

\begin{tabular}{|c|c|c|c|c|c|c|}
\hline $\begin{array}{l}\text { Author/ } \\
\text { Year }\end{array}$ & $\begin{array}{l}\text { No. of } \\
\text { patients }\end{array}$ & $\begin{array}{l}\text { BC } \\
\text { subtype }\end{array}$ & AR assessment & $\begin{array}{l}\text { Concomitant/ } \\
\text { experimental } \\
\text { treatment }\end{array}$ & $\begin{array}{l}\text { Definition } \\
\text { of AR }\end{array}$ & Prognostic value \\
\hline Kensler /2019 & 3021 & ER+ & $\mathrm{IHC}$ & Tamoxifen/ Letrozole & $\geq 1 \%$ & Not associated with prognosis \\
\hline Lehmann /2014 & 50 & TNBC & $\begin{array}{l}\text { FFPE sections, } \\
\text { DAKO clone } \\
\text { AR411 }\end{array}$ & No & $>30 \%$ & $\begin{array}{l}\text { Favorable in combination AR } \\
\text { antagonists with PI } 3 \mathrm{~K} / \mathrm{mTOR} \\
\text { inhibitors }\end{array}$ \\
\hline Conde /2004 & 39 & $\begin{array}{l}\text { CIS, } \\
\text { infiltrating } \\
\text { carcinoma }\end{array}$ & $\begin{array}{l}\text { IHC+ } \\
\text { immunobloting }\end{array}$ & Tamoxifen & No & $\begin{array}{l}\text { Presence of DAX-1 may interfere } \\
\text { with endocrine therapy }\end{array}$ \\
\hline Guiu /2018 & 333 & TNBC & $\mathrm{IHC}$ & No & $1 \%$ & $\mathrm{AR}+/$ FOXA1+ worse outcome \\
\hline Dieci /2019 & 263 & TNBC & $\mathrm{IHC}$ & $\begin{array}{l}\text { Neo/adjuvant } \\
\text { treatment }\end{array}$ & $1 \%$ & $\begin{array}{l}\mathrm{AR}+\text { is associated with worse } \\
\text { outcome }\end{array}$ \\
\hline Elebro /2017 & 910 & $\mathrm{BC}$ & IHC & Yes & $>10 \%$ & $\mathrm{AR}+/$ ER- worse prognosis \\
\hline Park /2009 & 413 & $\mathrm{BC}$ & $\mathrm{IHC}$ & No & $\geq 10 \%$ & $\begin{array}{l}\text { lower tumor burden and favorable } \\
\text { differentiation }\end{array}$ \\
\hline Gonzalez /2008 & 83 & $\mathrm{BC}$ & $\mathrm{IHC}$ & No & $>10 \%$ & $\begin{array}{l}\text { AR are represented in breast } \\
\text { cancer and are correlated with the } \\
\text { expression of some MMPs and } \\
\text { TIMP-2. }\end{array}$ \\
\hline Caiazza /2016 & 2091 & TNBC & IHC & Enzalutamide & $>10 \%$ & $\begin{array}{l}\text { Provide an alternative treatment for } \\
\text { patients with AR-positive TNBC. }\end{array}$ \\
\hline Traina $/ 2018$ & 57 & TNBC & IHC & Enzalutamide & $\geq 10 \%$ & Clinical efficacy, well tolerated \\
\hline Gucalp /2013 & 424 & $\begin{array}{l}\mathrm{ER} / \mathrm{PgR}- \\
\text { negative }\end{array}$ & $\mathrm{IHC}$ & Bicalutamide & $\geq 10 \%$ & $\begin{array}{l}\text { Efficacy, minimally toxic androgen } \\
\text { blockade }\end{array}$ \\
\hline Castellano /2010 & 953 & $\mathrm{ER}+$ & $\mathrm{IHC}$ & No & $10 \%$ & Prognostic factor of better outcome \\
\hline
\end{tabular}




\section{Androgens and hormone receptors positive}

The androgens (especially the testosterone) can provide dual effect on breast cell: a proliferative effect mediated by ER and an anti-proliferative effect mediated by AR. Studies showed that high levels of androgens, especially testosterone, increased the risk for $\mathrm{BC}$, regardless of hormonal status. Related to this aspect, the presence of an increased blood concentration of androgenic hormones may lead to tumor proliferation, especially in post- menopausal women [38,39].

The phase III trial by Breast International Group (Trial 1-98) assessed the AR expression among 3021 postmenopausal ER+ BC patients and compared 5 years of tamoxifen or letrozole monotherapy or sequences of two years and three years treatment with one drug and then the other. AR expression neither interferes with the prognosis of $\mathrm{BC}$ patients nor can it be categorized as a surrogate marker for individualizing endocrine therapy [40].

It is known that endocrine therapy plays an important role in BC treatment and turning cells into resistant one is an important threshold for physicians. Conde et al. showed that the presence of pattern DAX-1 (dosage-sensitive sex reversal, adrenal hypoplasia critical region, on chromosome $\mathrm{X}$, gene 1) in BC cells may interfere with the intracellular position of both AR and ER and consecutively affect the response to endocrine therapy [41].

\section{$A R$ and cerbB2 positive $B C$}

About half of the breast tumors which express cerbB2 over express AR. The presence of both receptors was associated with a higher frequency of ER and PgR expression, smaller tumor size, earlier clinical stage and lower Ki-67 level compared with AR negativity. Those findings concluded that co expression of both $\mathrm{AR}$ and cerbB2 might be associated with less aggressive tumor subtype [37,42].

\section{$A R$ and TNBC}

TNBC refers to breast tumors that do not express the genes for hormonal receptors (ER an PgR) and Her2/neu. This type of cancer is more frequent in younger women and people with BC type 1 susceptibility protein (BRCA 1) germline mutation [24,31].

This subtype was also sub classified taking into account the AR, the absence being called quadruple negative. AR expression has been found in $25-75 \%$ of TNBC were the AR seems to promote cell proliferation. It is because AR have demonstrated growth action in TNBC cell lines and in vivo models. Taking into account that for this type of tumor the only treatment possibility is with chemotherapy, AR seems to be a potential targeted therapy $[43,44]$.

Clinical studies results related to the influence of AR on the survival of patients with BC are controversial. Retrospectives studies suggested that the AR presence in TBNC is associated with prolonged disease-free survival compared with those with negative AR, with $1 \%$ cut-off for
IHC. Another study showed that the presence of AR might prolong both overall survival and disease-free survival, in non-metastatic patient, despite the pathological response after neo-adjuvant chemotherapy. In a recent study publish last year, Dieci et al. concluded that $\mathrm{AR}$ expression is associated with worsen outcome for TNBC patients [45-48].

$\mathrm{PI} 3 \mathrm{~K} / \mathrm{AKT} / \mathrm{mTOR}$ in an important pathway involved in $\mathrm{BC}$ development. The androgens up-regulates PTEN transcriptional expression when AR binds to specific cell sites in the PTEN upstream promoter. Subsequently, PTEN restrains PI3K action, which in turn weakens AR activity. In AR+ TNBC, the presence of PIK3CA mutation was higher than the AR negative, therefore dual targeting the AR and PI3K way leads to a synergistic anti- tumor effect [49-53].

In their study, Guiu et al. assessed in a TNBC population both AR and FOXA1 genes and estimated that those tumors are distinct of basal-like and represent $8-12 \%$ of all BC. The AR expression was present in 333 patients significant older and with more frequent nodal involvement then the AR negative tumors. The tumors presented lower histologic grades, lobular histology and PIK3CA mutations [54].

\section{AR targeted therapy}

Anti-androgen therapy is largely used in prostate cancer although the studies performed until now didn't demonstrate the efficacy of a drug. The first drug used for treatment of metastatic BC was fluoxymesterone and was used in the 1960s. Its use was stopped due to side effects, like hirsutism, hoarseness or alopecia, but also due to incomplete knowledge of the mechanism of action and patient selection $[55,56]$.

After this initial drug, both AR agonists and antagonist were used experimental in clinical studies. For patients with advanced $\mathrm{BC}$, with progression after hormonal therapy or TNBC, first (Bicalutamide) and second generation (Enzalutamide) AR antagonist were used. The first studies were positive, but there are necessary furthermore to demonstrate the efficacy and the tolerability of this drug. Inhibitors of androgen production, like CYP17A1- Abiraterone, were also used in phase 2 clinical trials, alone or in combination with AR antagonists [57-59].

The clinical and preclinical experience had shown that, in TNBC and Her+, AR stimulates proliferation of tumor cells in combination with other effectors like CDK4/6, MEK, and PI3KCA. Those mechanisms command the intracellular circuits leading to invasiveness, survival, proliferation and drug escape. Together with the inhibitors of these pathways, the AR antagonist can be a therapeutic option [60-62].

Also, the new generation anti-androgens have been studied in patients with metastatic BC, like flutamide or enzalutamide. These studies were performed on both cell lines and human sources in phase I or II studies. The first positive phase II trial was conducted by Traina et al., 
enrolled 118 patients, but only 78 were selected to receive enzalutimide and had the AR expression $\geq 10 \%$. Most patients received systemic adjuvant treatment of locally advance $\mathrm{BC}$ or for metastases TNBC. The primary end point was the benefit rate at 16 weeks, defined as confirmed complete response (CR) or partial response or stable disease at study week 16. Enzalutamide demonstrated clinical efficacy and was well tolerated. Further studies are needed for use in daily practice [59].

\section{Discussion}

Various combined-modality therapies, which are used nowadays such as surgery, endocrine therapy, chemotherapy, targeted therapy, radiation therapy and last but not least, immunotherapy, have improved the outcomes in patients with BC. However, metastasis and recurrence are considered major contributors to treatment failure. Current knowledge of etiopathology, biology, and treatment protocols of breast cancer has benefited from the simultaneous analysis of multiple biomarkers, such as ER, PR, HER2, Ki67, PD-L1 or PIK3CA. These markers are essential in identifying a high-risk phenotype and determining the most efficient therapeutic strategies. However, since breast cancer is a complex and heterogenetic disease, these markers could not cover all disease features. Therefore, it is important to find out new markers with predictive value for survival of patients with breast cancer $[63,64]$.

In the past decades, androgens have been identified to improve the efficacy of hormonal treatment and have been used to treat advanced breast cancer; however, their use has declined with the advent of tamoxifen. Androgens and AR may have some important roles in breast cancer. Some studies have examined and indicated that androgen acts through AR in carcinoma cells and play important roles in biology and clinical behaviour of breast cancer model systems and cell lines [65-67].

The current interest in AR in BC is increasing. AR is a promising primary target for treatment in ER-population and especially in TNBC, were the treatment options are chemotherapy or immunotherapy, more recently. In the TNBC the outcome impact of the presence of those receptors is controversial, with improved or decreased survival. Further studies are necessary to identify which patients may benefit from this therapy [24,68,69].

The roles of androgen and AR in BC and their roles in developing or promoting cancer development are partial unknown. Some of the clinical studies report association between AR expression and prognostic, others no [2,36].

Another aspect studied was the association of AR with other membrane receptor or cell compound like several matrix metalloproteases (MMPs) and their inhibitors (TIMPs). The assessed of both cell compound was high in the positive cells and was correlated with the prognosis [70].
In ER positive $\mathrm{BC}$ cell, the $\mathrm{AR}$ effect appeared to be dual. AR expression is an independent prognostic factor of better outcome in patients with ER-positive BC, but there are also publications that conclude there is no correlation between the presence of these receptors and neoplastic development $[35,71,72]$.

TNBC has the poorest outcome of the three major subtypes of BC. Numerous studies have aimed to find targeted therapies for this aggressive disease, but so far there are modest result on overall survival and diseasefree survival highlight the high- risk of recurrence and metastasis. The discovery of an anti- androgenic therapy has been evaluated in several studies, with promising results, but without use in clinical practice [59,73-75].

\section{Conclusions}

This review summarizes the data concerning the mechanism of action and the role of $\mathrm{AR}$ in $\mathrm{BC}$, but also the acquired knowledge regarding the anti-androgenic therapy. $\mathrm{BC}$ is a heterogeneous disease with a high mortality, despite the numerous therapeutic agents and strategies. AR can be present in $60 \%$ of breast tumor cells and can modulate the growth and progression. Together with ER, AR is frequently expressed, suggesting pivotal expression in progression of BC. In ER positive patients, the AR can either inhibit or promote the $\mathrm{BC}$ cell growth, while it predominantly stimulates the cell proliferation in ER negative BC patients. The effect can be done in an independent manner or in combination with other targeted therapy.

In $\mathrm{TNBC}$ the data showed that $\mathrm{AR}$ expression seemed to be a favorable prognostic factor. Routine assessment of AR and also the cut-off may help identifying patients who will benefit from AR therapy. Especially in this particular subtype, AR is an emerging and promising therapeutic target, both because the lack of therapeutic possibilities and the bad prognostic.

To conclude, increased understanding of the AR role, which can benefit from AR targeted therapy and what drugs are effective for AR positive tumor, are some aspects which may potentially prove to be treatment options for $\mathrm{BC}$ patients.

\section{References}

1. Omata F, McNamara KM, Suzuki K, Abe E, Hirakawa H, Ishida $\mathrm{T}$, et al. Effect of the normal mammary differentiation regulator ELF5 upon clinical outcomes of triple negative breast cancers patients. Breast Cancer. 2018;25:489-496.

2. Schippinger W, Regitnig P, Dandachi N, Wernecke KD, Bauernhofer T, Samonigg $H$, et al. Evaluation of the prognostic significance of androgen receptor expression in metastatic breast cancer. Virchows Arch. 2006;449:24-30.

3. Hu R, Dawood S, Holmes MD, Collins LC, Schnitt SJ, Cole $\mathrm{K}$, et al. Androgen receptor expression and breast cancer survival in postmenopausal women. Clin Cancer Res. 
2011;17:1867-1874.

4. Manolescu L. Association of hepatitis B infection in patients with HIV Encephalopathy. Romanian Biotechnological Letters. 2012;17.

5. Tampa M, Mitran CI, Mitran MI, Nicolae I, Dumitru A, Matei C, et al. The Role of Beta HPV Types and HPVAssociated Inflammatory Processes in Cutaneous Squamous Cell Carcinoma. J Immunol Res. 2020;2020:5701639.

6. Manolescu L, Marinescu P. Sex differences in HIV-1 viral load and absolute CD4 cell count in long term survivors HIV-1 infected patients from Giurgiu, Romania. Romanian Review of Laboratory Medicine. 2013;21.

7. Manolescu LSC, Boeru C, Căruntu C, Dragomirescu CC, Goldis M, Jugulete $\mathrm{G}$, et al. A Romanian experience of syphilis in pregnancy and childbirth. Midwifery. 2019;78:5863.

8. Dragomirescu CC, Lixandru BE, Coldea IL, Corneli ON, Pana M, Palade AM, et al. Antimicrobial Susceptibility Testing for Corynebacterium Species Isolated from Clinical Samples in Romania. Antibiotics (Basel). 2020;9:31.

9. Cardoso F, Kyriakides S, Ohno S, Penault-Llorca F, Poortmans P, Rubio IT, et al. Early breast cancer: ESMO Clinical Practice Guidelines for diagnosis, treatment and follow-up. Ann Oncol. 2019;30:1194-1220.

10. Ellis MJ, Suman VJ, Hoog J, Goncalves R, Sanati S, Creighton CJ, et al. Ki67 Proliferation Index as a Tool for Chemotherapy Decisions During and After Neoadjuvant Aromatase Inhibitor Treatment of Breast Cancer: Results From the American College of Surgeons Oncology Group Z1031 Trial (Alliance). J Clin Oncol. 2017;35:1061-1069.

11. Cardoso F, Kyriakides S, Ohno S, Penault-Llorca F, Poortmans P, Rubio IT, Zackrisson S, Senkus E; ESMO Guidelines Committee. Electronic address: clinicalguidelines@esmo. org. Early breast cancer: ESMO Clinical Practice Guidelines for diagnosis, treatment and follow-up $\uparrow$. Ann Oncol. 2019 Aug 1;30(8):1194-1220. doi: 10.1093/annonc/mdz173.

12. Bianchini G, Balko JM, Mayer IA, Sanders ME, Gianni L. Triple-negative breast cancer: challenges and opportunities of a heterogeneous disease. Nat Rev Clin Oncol. 2016;13:674690.

13. Moinfar F, Okcu M, Tsybrovskyy O, Regitnig P, Lax SF, Weybora W, et al. Androgen receptors frequently are expressed in breast carcinomas: potential relevance to new therapeutic strategies. Cancer. 2003;98:703-711.

14. Collins LC, Cole KS, Marotti JD, Hu R, Schnitt SJ, Tamimi RM. Androgen receptor expression in breast cancer in relation to molecular phenotype: results from the Nurses' Health Study. Mod Pathol. 2011;24:924-931.

15. Kono M, Fujii T, Lim B, Karuturi MS, Tripathy D, Ueno NT. Androgen Receptor Function and Androgen ReceptorTargeted Therapies in Breast Cancer: A Review. JAMA oncology. 2017;3(9):1266-73.

16. Bozovic-Spasojevic I, Zardavas D, Brohée S, Ameye L, Fumagalli D, Ades F, et al. The Prognostic Role of Androgen Receptor in Patients with Early-Stage Breast Cancer: A Meta-analysis of Clinical and Gene Expression Data. Clin Cancer Res. 2017;23:2702-2712.
17. Barton VN, D'Amato NC, Gordon MA, Christenson JL, Elias A, Richer JK. Androgen Receptor Biology in Triple Negative Breast Cancer: a Case for Classification as AR+ or Quadruple Negative Disease. Horm Cancer. 2015;6:206-213.

18. Guyton AC HJ. Textbook of Medical Physiology. $11^{\text {th }}$ edition, pag. 905-1052. Elsevier Saunders, Philadelphia 2006.

19. Kotsopoulos J, Narod SA. Androgens and breast cancer. Steroids. 2012;77:1-9.

20. Solomon ZJ, Mirabal JR, Mazur DJ, Kohn TP, Lipshultz LI, Pastuszak AW. Selective Androgen Receptor Modulators: Current Knowledge and Clinical Applications. Sex Med Rev. 2019;7:84-94.

21. Claessens F, Denayer S, Van Tilborgh N, Kerkhofs S, Helsen C, Haelens A. Diverse roles of androgen receptor (AR) domains in AR-mediated signaling. Nucl Recept Signal. 2008;6:e008.

22. Gelmann EP. Molecular biology of the androgen receptor. $J$ Clin Oncol. 2002;20:3001-3015.

23. Peters AA, Buchanan G, Ricciardelli C, Bianco-Miotto T, Centenera MM, Harris JM, et al. Androgen receptor inhibits estrogen receptor-alpha activity and is prognostic in breast cancer. Cancer Res. 2009;69:6131-6140.

24. Lehmann BD, Bauer JA, Chen X, Sanders ME, Chakravarthy $\mathrm{AB}$, Shyr Y, et al. Identification of human triple-negative breast cancer subtypes and preclinical models for selection of targeted therapies. J Clin Invest. 2011;121:2750-2767.

25. Burstein MD, Tsimelzon A, Poage GM, Covington KR, Contreras A, Fuqua SA, et al. Comprehensive genomic analysis identifies novel subtypes and targets of triple-negative breast cancer. Clin Cancer Res. 2015;21:1688-1698.

26. Sanga S, Broom BM, Cristini V, Edgerton ME. Gene expression meta-analysis supports existence of molecular apocrine breast cancer with a role for androgen receptor and implies interactions with ErbB family. BMC Med Genomics. 2009;2:59.

27. Weigelt B, Horlings HM, Kreike B, Hayes MM, Hauptmann M, Wessels LF, et al. Refinement of breast cancer classification by molecular characterization of histological special types. J Pathol. 2008;216:141-150.

28. Garcia X, Elia A, Galizzi L, May M, Spengler E, Martinez Vázquez $\mathrm{P}$, et al. Increased androgen receptor expression in estrogen receptor-positive/progesterone receptor-negative breast cancer. Breast Cancer Res Treat. 2020;180:257-263.

29. Ravaioli S, Tumedei MM, Foca F, Maltoni R, Rocca A, Massa I, et al. Androgen and oestrogen receptors as potential prognostic markers for patients with ductal carcinoma in situ treated with surgery and radiotherapy. Int J Exp Pathol. 2017;98:289-295.

30. D'Amato NC, Gordon MA, Babbs B, Spoelstra NS, Carson Butterfield KT, Torkko KC, et al. Cooperative Dynamics of AR and ER Activity in Breast Cancer. Mol Cancer Res. 2016;14:1054-1067.

31. Shah PD, Gucalp A, Traina TA. The role of the androgen receptor in triple-negative breast cancer. Womens Health (Lond). 2013;9:351-360.

32. Park S, Koo JS, Kim MS, Park HS, Lee JS, Lee JS, et al. Androgen receptor expression is significantly associated 
with better outcomes in estrogen receptor-positive breast cancers. Ann Oncol. 2011;22:1755-1762.

33. Yu Q, Niu Y, Liu N, Zhang JZ, Liu TJ, Zhang RJ, et al. Expression of androgen receptor in breast cancer and its significance as a prognostic factor. Ann Oncol. 2011;22:12881294.

34. Park S, Koh E, Koo JS, Kim SI, Park BW, Kim KS. Lack of both androgen receptor and forkhead box A1 (FOXA1) expression is a poor prognostic factor in estrogen receptorpositive breast cancers. Oncotarget. 2017;8:82940-82955.

35. Castellano I, Allia E, Accortanzo V, Vandone AM, Chiusa L, Arisio R, et al. Androgen receptor expression is a significant prognostic factor in estrogen receptor positive breast cancers. Breast Cancer Res Treat. 2010;124:607-617.

36. Elebro K, Bendahl PO, Jernström H, Borgquist S. Androgen receptor expression and breast cancer mortality in a population-based prospective cohort. Breast Cancer Res Treat. 2017;165:645-657.

37. Park S, Koo J, Park HS, Kim JH, Choi SY, Lee JH, et al. Expression of androgen receptors in primary breast cancer. Ann Oncol. 2010;21:488-492.

38. Søiland H, Kørner H, Skaland I, Janssen EA, Gudlaugsson E, Varhaug JE, et al. Prognostic relevance of androgen receptor detection in operable breast cancer. J Surg Oncol. 2008;98:551-558.

39. Agrawal AK, Jeleń M, Grzebieniak Z, Zukrowski P, Rudnicki J, Nienartowicz E. Androgen receptors as a prognostic and predictive factor in breast cancer. Folia Histochem Cytobiol. 2008;46:269-276.

40. Castoria G, Lombardi M, Barone MV, Bilancio A, Di Domenico M, Bottero D, et al. Androgen-stimulated DNA synthesis and cytoskeletal changes in fibroblasts by a nontranscriptional receptor action. J Cell Biol. 2003;161:547556.

41. Conde I, Alfaro JM, Fraile B, Ruíz A, Paniagua R, Arenas MI. DAX-1 expression in human breast cancer: comparison with estrogen receptors ER-alpha, ER-beta and androgen receptor status. Breast Cancer Res. 2004;6:R140-R148.

42. Lin Fde M, Pincerato KM, Bacchi CE, Baracat EC, Carvalho FM. Coordinated expression of oestrogen and androgen receptors in HER2-positive breast carcinomas: impact on proliferative activity. J Clin Pathol. 2012;65:64-68.

43. Rampurwala M, Wisinski KB, O'Regan R. Role of the androgen receptor in triple-negative breast cancer. Clin Adv Hematol Oncol. 2016;14:186-193.

44. Gucalp A, Traina TA. Targeting the androgen receptor in triple-negative breast cancer. Curr Probl Cancer. 2016;40:141-150.

45. Loibl S, Müller BM, von Minckwitz G, Schwabe M, Roller M, Darb-Esfahani S, et al. Androgen receptor expression in primary breast cancer and its predictive and prognostic value in patients treated with neoadjuvant chemotherapy. Breast Cancer Res Treat. 2011;130:477-487.

46. Thike AA, Yong-Zheng Chong L, Cheok PY, Li HH, WaiCheong Yip G, Huat Bay B, et al. Loss of androgen receptor expression predicts early recurrence in triple-negative and basal-like breast cancer. Mod Pathol. 2014;27:352-360.
47. Zuo T, Wilson P, Cicek AF, Harigopal M. Androgen receptor expression is a favorable prognostic factor in triple-negative breast cancers. Hum Pathol. 2018;80:239-245.

48. Dieci MV, Tsvetkova V, Griguolo G, Miglietta F, Mantiero M, Tasca G, et al. Androgen Receptor Expression and Association With Distant Disease-Free Survival in Triple Negative Breast Cancer: Analysis of 263 Patients Treated With Standard Therapy for Stage I-III Disease. Front Oncol. 2019;9:452.

49. Costa RLB, Han HS, Gradishar WJ. Targeting the PI3K/ AKT/mTOR pathway in triple-negative breast cancer: a review. Breast Cancer Res Treat. 2018;169:397-406.

50. Lehmann BD, Bauer JA, Schafer JM, Pendleton CS, Tang L, Johnson $\mathrm{KC}$, et al. PIK3CA mutations in androgen receptorpositive triple negative breast cancer confer sensitivity to the combination of PI3K and androgen receptor inhibitors. Breast Cancer Res. 2014;16:406.

51. Wang J, Zhang C, Chen K, Tang H, Tang J, Song C, et al. ER $\beta 1$ inversely correlates with PTEN/PI3K/AKT pathway and predicts a favorable prognosis in triple-negative breast cancer. Breast Cancer Res Treat. 2015;152:255-269.

52. Wang Y, Romigh T, He X, Tan MH, Orloff MS, Silverman $\mathrm{RH}$, et al. Differential regulation of PTEN expression by androgen receptor in prostate and breast cancers. Oncogene. 2011;30:4327-4338.

53. Omarini C, Filieri ME, Bettelli S, Manfredini S, Kaleci S, Caprera C, et al. Mutational Profile of Metastatic Breast Cancer Tissue in Patients Treated with Exemestane Plus Everolimus. Biomed Res Int. 2018;2018:3756981.

54. Guiu S, Mollevi C, Charon-Barra C, Boissière F, Crapez E, Chartron E, et al. Prognostic value of androgen receptor and FOXA1 co-expression in non-metastatic triple negative breast cancer and correlation with other biomarkers. Br J Cancer. 2018;119:76-79.

55. Kono M, Fujii T, Lyons GR, Huo L, Bassett R, Gong Y, et al. Impact of androgen receptor expression in fluoxymesteronetreated estrogen receptor-positive metastatic breast cancer refractory to contemporary hormonal therapy. Breast Cancer Res Treat. 2016;160:101-109.

56. Cochrane DR, Bernales S, Jacobsen BM, Cittelly DM, Howe $\mathrm{EN}$, D'Amato NC, et al. Role of the androgen receptor in breast cancer and preclinical analysis of enzalutamide. Breast Cancer Res. 2014;16:R7.

57. Huang R, Han J, Liang X, Sun S, Jiang Y, Xia B, et al. Androgen Receptor Expression and Bicalutamide Antagonize Androgen Receptor Inhibit $\beta$-Catenin Transcription Complex in Estrogen Receptor-Negative Breast Cancer. Cell Physiol Biochem. 2017;43:2212-2225.

58. Gucalp A, Tolaney S, Isakoff SJ, Ingle JN, Liu MC, Carey LA, et al. Phase II trial of bicalutamide in patients with androgen receptor-positive, estrogen receptor-negative metastatic Breast Cancer. Clin Cancer Res. 2013;19:55055512.

59. Traina TA, Miller K, Yardley DA, Eakle J, Schwartzberg LS, O'Shaughnessy J, et al. Enzalutamide for the Treatment of Androgen Receptor-Expressing Triple-Negative Breast Cancer. J Clin Oncol. 2018;36:884-890. 
60. Li L, Karanika S, Yang G, Wang J, Park S, Broom BM, et al. Androgen receptor inhibitor-induced "BRCAness" and PARP inhibition are synthetically lethal for castrationresistant prostate cancer. Sci Signal. 2017;10:eaam7479.

61. Bareche Y, Venet D, Ignatiadis M, Aftimos P, Piccart M, Rothe F, et al. Unravelling triple-negative breast cancer molecular heterogeneity using an integrative multiomic analysis. Ann Oncol. 2018;29:895-902.

62. Cuorvo LV, Verderio P, Ciniselli CM, Girlando S, Decarli $\mathrm{N}$, Leonardi $\mathrm{E}$, et al. PI3KCA mutation status is of limited prognostic relevance in ER-positive breast cancer patients treated with hormone therapy. Virchows Arch. 2014;464:8593.

63. Weigelt B, Peterse JL, van 't Veer LJ. Breast cancer metastasis: markers and models. Nat Rev Cancer. 2005;5:591-602.

64. Banin Hirata BK, Oda JM, Losi Guembarovski R, Ariza $\mathrm{CB}$, de Oliveira CE, Watanabe MA. Molecular markers for breast cancer: prediction on tumor behavior. Dis Markers. 2014;2014:513158.

65. Ingle JN, Twito DI, Schaid DJ, Cullinan SA, Krook JE, Mailliard JA, et al. Combination hormonal therapy with tamoxifen plus fluoxymesterone versus tamoxifen alone in postmenopausal women with metastatic breast cancer. An updated analysis. Cancer. 1991;67:886-891.

66. Peters AA, Ingman WV, Tilley WD, Butler LM. Differential effects of exogenous androgen and an androgen receptor antagonist in the peri- and postpubertal murine mammary gland. Endocrinology. 2011;152:3728-3737.

67. Naderi A, Chia KM, Liu J. Synergy between inhibitors of androgen receptor and MEK has therapeutic implications in estrogen receptor-negative breast cancer. Breast Cancer Res. 2011;13:R36.

68. Farmer P, Bonnefoi H, Becette V, Tubiana-Hulin M,
Fumoleau P, Larsimont D, et al. Identification of molecular apocrine breast tumors by microarray analysis. Oncogene. 2005;24:4660-4671.

69. Doane AS, Danso M, Lal P, Donaton M, Zhang L, Hudis $\mathrm{C}$, et al. An estrogen receptor-negative breast cancer subset characterized by a hormonally regulated transcriptional program and response to androgen. Oncogene. 2006;25:39944008.

70. Gonzalez LO, Corte MD, Vazquez J, Junquera S, Sanchez $\mathrm{R}$, Alvarez AC, et al. Androgen receptor expresion in breast cancer: relationship with clinicopathological characteristics of the tumors, prognosis, and expression of metalloproteases and their inhibitors. BMC Cancer. 2008;8:149.

71. Kensler KH, Regan MM, Heng YJ, Baker GM, Pyle ME, Schnitt SJ, et al. Prognostic and predictive value of androgen receptor expression in postmenopausal women with estrogen receptor-positive breast cancer: results from the Breast International Group Trial 1-98. Breast Cancer Res. 2019;21:30.

72. Kensler KH, Beca F, Baker GM, Heng YJ, Beck AH, Schnitt $\mathrm{SJ}$, et al. Androgen receptor expression in normal breast tissue and subsequent breast cancer risk. NPJ Breast Cancer. 2018;4:33.

73. Twelves C, Cortes J, Vahdat L, Olivo M, He Y, Kaufman PA, et al. Efficacy of eribulin in women with metastatic breast cancer: a pooled analysis of two phase 3 studies. Breast Cancer Res Treat. 2014;148:553-561.

74. Kast K, Link T, Friedrich K, Petzold A, Niedostatek A, Schoffer $\mathrm{O}$, et al. Impact of breast cancer subtypes and patterns of metastasis on outcome. Breast Cancer Res Treat. 2015;150:621-629.

75. Chacón RD, Costanzo MV. Triple-negative breast cancer. Breast Cancer Res. 2010;12 Suppl 2(Suppl 2):S3. 